\title{
Feeding Practices Followed by Nili Ravi Buffalo Farmers in Different Agroclimatic Zones of Punjab
}

\author{
Navkiran Kaur*, H.K. Verma, Jaswinder Singh and S.K. Kansal \\ Department of Veterinary and Animal Husbandry Extension Education, College of Veterinary \\ Science, Guru Angad Dev Veterinary and Animal Sciences University, \\ Ludhiana, 141001, India \\ *Corresponding author
}

Keywords

Feeding practices, Nili Ravi buffalo farmers, Mineral mixture, Silage,

Concentrate

Article Info

Accepted:

10 September 2020

Available Online:

10 October 2020

\section{A B S T R A C T}

A purposive study was conducted on 300 Nili Ravi buffalo farmers selected from four agroclimatic zones of Punjab. The data was collected by personal interview cum questionnaire schedule consisting the feeding practices followed by the farmers. Data revealed that Majority $(86.33 \%)$ of the farmers were doing group feeding and only (13.67\%) of the farmers were doing individual feeding. Majority $(63.67 \%)$ of farmers were feeding extra diet to pregnant animals \& maximum (73.33\%) were from ACZ I(Asr). Majority $(53.33 \%)$ of farmers was feeding mineral mixture to the animals and maximum proportion $(98.67 \%)$ of the Nili Ravi farmers was feeding concentrate to the buffaloes. Majority of the farmers $(78 \%)$ were feeding common salt. Only $29.67 \%$ of the farmers were feeding silage and $12.33 \%$ of the farmers were feeding urea molasses block to the animals.

\section{Introduction}

Livestock sector plays a vital role in the Indian economy and also in the socioeconomic development of millions of rural households. The total Livestock population is 535.78 million in the country. Total Bovine population (Cattle, Buffalo etc.) is 302.79 Million in 2019 which shows an increase of $1.0 \%$ over the last census $\left(20^{\text {th }}\right.$ livestock census, DAHD). Dairying has become an important secondary source of income for millions of rural families and has assumed the most important role in providing employment and income generating opportunities particularly for women and marginal farmers. Milk Production during 2016-17 and 2017-18 are 165.4 million tonnes and 176.3 million tonnes respectively showing an annual growth of $6.62 \%$. The per capita availability of milk 
is around 375 grams per day in 201718(Annual report 2018-19, DAHD).

The buffalo holds an important place in Indian rural economy. About $20.5 \%$ of the total livestock is contributed by buffaloes $\left(20^{\text {th }}\right.$ livestock census, DAHD). Buffalo is considered as the dairy animal for $21^{\text {st }}$ century due to its higher adaptability and productivity in changing climatic conditions (Siddiky and Faruque, 2017). Total Buffalo Population in the country is 109.85 Million during 2019 $\left(20^{\text {th }}\right.$ livestock census, DAHD). Total buffalo population in Punjab is around 40 lac. In the Punjab buffaloes contribute to 6,575 ('000MT) of milk production in the year 2012-13(A statistical profile 2014, NDDB). There are 12 standard breeds of buffaloes in the country (A statistical profile 2014, NDDB). The Nili Ravi is the breed of domestic water buffalo. It is a dynamic breed under field conditions (Ali et al., 2014).

Nili-Ravi buffaloes are found in almost all the districts, with major concentration in Amritsar, Gurdaspur and Ferozepur districts of Punjab, India (Buffalopedia, ICAR). Nili Ravi contributes $6.94 \%$ of total buffalo population in Punjab. The estimated population of Nili Ravi type of buffaloes in their breeding tracts (Ferozpur, Amritsar, Gurdaspur) is around 0.2 million (Vij and Tantia, 2005). In 2007 the total population of Nili-Ravi buffalo was 384000 in Punjab(A statistical profile 2014, NDDB). As Nili Ravi is native breed of Punjab which is kept for dairy, draft and meat purpose however not much information is available on rearing practices of such buffaloes ,keeping this in mind study has been planned.

\section{Materials and Methods}

The study was conducted in the four agroclimatic zones of Punjab, depending upon the availability of Nili Ravi buffaloes, these zones were- central plain zone, western plain zone, western zone and sub mountain undulating zone. From each zone, districts were selected. From central plain zoneAmritsar \& tarn taran was selected, from western plain zone- ferozpur was selected, from western zone- moga was selected and from sub mountain undulating zoneGurdaspur was selected. From each district, further two tehsils were selected and from each tehsil further two villages were selected, from each village 15 respondents were selected, thus from each district 60 respondents were selected so total 300 Nili Ravi buffalo farmers were selected. The data was collected on feeding practices with the help of questionnaire cum interview schedule ,the collected data were carefully examined for its completeness and correctness before tabulation . for analysis, simple tabular techniques and standard appropriate statistical methods and tools like SPSS 20.0 and Microsoft excel were used.

\section{Results and Discussion}

\section{Feeding frequency}

Table 1 represents the distribution of Nili Ravi buffalo farmers according to the feeding frequency. Out of 300 farmers, major proportion (95.33\%) of the farmers was feeding twice a day to the animals followed by $4.67 \%$ farmers feeding thrice a day. Majority $(100 \%)$ of the farmers who were feeding twice a day were from ACZ IV and minimum (86.67\%) were from ACZ I(TT). Those who were feeding thrice a day, majority $(13.33 \%)$ of the farmers were from ACZ I (TT) and minimum proportion (0\%) from ACZ IV.

No farmer was feeding once a day to the buffaloes.

Dar et al., (2017) had reported in their studies that maximum $(76.50 \%)$ of the farmers were feeding twice a day and these findings are similar to our findings. 


\section{Method of feeding}

Table 1 depicts the distribution of Nili Ravi buffalo farmers according to method of feeding and it is revealed that only (13.67\%) of the farmers are doing individual feeding and majority $(86.33 \%)$ of the farmers are doing group feeding. Farmers doing individual feeding, majority $(26.67 \%)$ of the farmers were from ACZ III and minimum (6.67\%) were from ACZ I( TT) and ACZ III. Farmers doing group feeding, maximum farmers $(93.33 \%)$ were from ACZ I(TT) and ACZ III and minimum(73.33\%) were from ACZ III (Fig. 1).

Chavan et al., (2008) had reported in their studies that only $13 \%$ of the farmers were doing individual feeding.

\section{Feeding extra diet to pregnant animals}

Out of 300 Nili Ravi farmers, majority(63.67 $\%$ of farmers are feeding extra diet to pregnant animals and $36.33 \%$ are not feeding any extra diet, as explained in table 1 . Out of farmers feeding diet to pregnant animals, maximum $(73.33 \%)$ were from ACZ I (Asr) and minimum (46.67\%) were from ACZ II. For those who are not feeding extra diet, maximum $(53.33 \%)$ were from ACZ II and minimum (33.33\%) were from ACZ I (TT) and ACZ IV.

Table.1 Distribution of NR Buffalo farmers according to feeding frequency, method of feeding $\&$ feeding of extra diet to pregnant animals

\begin{tabular}{|c|c|c|c|c|c|c|c|}
\hline \multirow[t]{2}{*}{ Parameter } & \multirow[t]{2}{*}{ Category } & \multicolumn{2}{|c|}{ ACZ I } & \multirow{2}{*}{$\begin{array}{c}\text { ACZ II } \\
\begin{array}{c}\text { Frz } \\
(n=60)\end{array}\end{array}$} & \multirow{2}{*}{$\begin{array}{c}\text { ACZ } \\
\text { III } \\
\text { Moga } \\
(n=60)\end{array}$} & \multirow{2}{*}{$\begin{array}{c}\text { ACZ IV } \\
\qquad \begin{array}{c}\text { Grd } \\
(n=60)\end{array}\end{array}$} & \multirow{2}{*}{$\begin{array}{l}\text { Overall } \\
(n=300)\end{array}$} \\
\hline & & $\begin{array}{c}\text { Asr } \\
(n=60)\end{array}$ & $\begin{array}{c}\text { TT } \\
(n=60)\end{array}$ & & & & \\
\hline \multirow[t]{3}{*}{$\begin{array}{l}\text { Feeding } \\
\text { frequency }\end{array}$} & Once & $\begin{array}{c}0 \\
(0)\end{array}$ & $\begin{array}{c}0 \\
(0)\end{array}$ & $\begin{array}{c}0 \\
(0)\end{array}$ & $\begin{array}{c}0 \\
(0)\end{array}$ & $\begin{array}{c}0 \\
(0)\end{array}$ & $\begin{array}{c}0 \\
(0)\end{array}$ \\
\hline & Twice & $\begin{array}{c}59 \\
(98.33)\end{array}$ & $\begin{array}{c}52 \\
(86.67)\end{array}$ & $\begin{array}{c}57 \\
(95)\end{array}$ & $\begin{array}{c}58 \\
(96.67)\end{array}$ & $\begin{array}{c}60 \\
(100)\end{array}$ & $\begin{array}{c}286 \\
(95.33)\end{array}$ \\
\hline & Thrice & $\begin{array}{c}1 \\
(1.67)\end{array}$ & $\begin{array}{c}8 \\
(13.33)\end{array}$ & $\begin{array}{c}3 \\
(5)\end{array}$ & $\begin{array}{c}2 \\
(3.33)\end{array}$ & $\begin{array}{c}0 \\
(0)\end{array}$ & $\begin{array}{c}14 \\
(4.67)\end{array}$ \\
\hline \multirow[t]{2}{*}{$\begin{array}{l}\text { Method of } \\
\text { feeding }\end{array}$} & Individual & $\begin{array}{c}9 \\
(15)\end{array}$ & $\begin{array}{c}4 \\
(6.67)\end{array}$ & $\begin{array}{c}8 \\
(13.33)\end{array}$ & $\begin{array}{c}16 \\
(26.67)\end{array}$ & $\begin{array}{c}4 \\
(6.67)\end{array}$ & $\begin{array}{c}41 \\
(13.67)\end{array}$ \\
\hline & Group & $\begin{array}{c}51 \\
(85)\end{array}$ & $\begin{array}{c}56 \\
(93.33)\end{array}$ & $\begin{array}{c}52 \\
(86.67)\end{array}$ & $\begin{array}{c}44 \\
(73.33)\end{array}$ & $\begin{array}{c}56 \\
(93.33)\end{array}$ & $\begin{array}{c}259 \\
(86.33)\end{array}$ \\
\hline \multirow{2}{*}{$\begin{array}{c}\text { Pregnant } \\
\text { animals(extra } \\
\text { diet) }\end{array}$} & Yes & $\begin{array}{c}44 \\
(73.33)\end{array}$ & $\begin{array}{c}40 \\
(66.67)\end{array}$ & $\begin{array}{c}28 \\
(46.67)\end{array}$ & $\begin{array}{c}39 \\
(65)\end{array}$ & $\begin{array}{c}40 \\
(66.67)\end{array}$ & $\begin{array}{c}191 \\
(63.67)\end{array}$ \\
\hline & No & $\begin{array}{c}16 \\
(26.67)\end{array}$ & $\begin{array}{c}20 \\
(33.33)\end{array}$ & $\begin{array}{c}32 \\
(53.33)\end{array}$ & $\begin{array}{c}21 \\
(35)\end{array}$ & $\begin{array}{c}20 \\
(33.33)\end{array}$ & $\begin{array}{c}109 \\
(36.33)\end{array}$ \\
\hline
\end{tabular}

Figure in parenthesis indicate \%age 
Table.2 Distribution of NR Buffalo farmers according to mineral mixture feeding, concentrate feeding and type of concentrate

\begin{tabular}{|c|c|c|c|c|c|c|c|}
\hline \multirow[t]{2}{*}{ Parameter } & \multirow[t]{2}{*}{ Category } & \multicolumn{2}{|c|}{ ACZ I } & \multirow{2}{*}{$\underset{\substack{\text { Frz } \\
(\mathbf{n}=60)}}{\text { ACZ II }}$} & \multirow{2}{*}{$\begin{array}{c}\text { ACZ III } \\
\begin{array}{c}\text { Moga } \\
(\mathbf{n}=60)\end{array}\end{array}$} & \multirow{2}{*}{$\underset{\substack{\text { Grd } \\
(\mathrm{n}=60)}}{\mathrm{ACZ} \text { IV }}$} & \multirow{2}{*}{$\begin{array}{l}\text { Overall } \\
(\mathbf{n}=300)\end{array}$} \\
\hline & & $\begin{array}{c}\text { Asr } \\
(\mathrm{n}=60)\end{array}$ & $\begin{array}{c}\text { TT } \\
(\mathrm{n}=60)\end{array}$ & & & & \\
\hline \multirow{2}{*}{$\begin{array}{l}\text { Mineral } \\
\text { mixture } \\
\text { feeding }\end{array}$} & Yes & $\begin{array}{c}18 \\
(30)\end{array}$ & $\begin{array}{l}42 \\
(70)\end{array}$ & $\begin{array}{c}34 \\
(56.67)\end{array}$ & $\begin{array}{c}44 \\
(73.33)\end{array}$ & $\begin{array}{c}22 \\
(36.67)\end{array}$ & $\begin{array}{c}160 \\
(53.33)\end{array}$ \\
\hline & No & $\begin{array}{c}42 \\
(70)\end{array}$ & $\begin{array}{c}18 \\
(30)\end{array}$ & $\begin{array}{c}26 \\
(43.33)\end{array}$ & $\begin{array}{c}16 \\
(26.67)\end{array}$ & $\begin{array}{c}38 \\
(63.33)\end{array}$ & $\begin{array}{c}140 \\
(46.67)\end{array}$ \\
\hline \multirow[t]{2}{*}{$\begin{array}{l}\text { Concentrate } \\
\text { feeding }\end{array}$} & Yes & $\begin{array}{c}56 \\
(93.33)\end{array}$ & $\begin{array}{c}60 \\
(100)\end{array}$ & $\begin{array}{c}60 \\
(100)\end{array}$ & $\begin{array}{c}60 \\
(100)\end{array}$ & $\begin{array}{c}60 \\
(100)\end{array}$ & $\begin{array}{c}296 \\
(98.67)\end{array}$ \\
\hline & No & $\begin{array}{c}4 \\
(6.67)\end{array}$ & $\begin{array}{c}0 \\
(0)\end{array}$ & $\begin{array}{c}0 \\
(0)\end{array}$ & $\begin{array}{c}0 \\
(0)\end{array}$ & $\begin{array}{c}0 \\
(0)\end{array}$ & $\begin{array}{c}4 \\
(1.33)\end{array}$ \\
\hline \multirow{3}{*}{$\begin{array}{l}\text { Type of } \\
\text { concentrate }\end{array}$} & Homemade & $\begin{array}{c}7 \\
(12.5)\end{array}$ & $\begin{array}{c}11 \\
(18.33)\end{array}$ & $\begin{array}{c}10 \\
(16.67)\end{array}$ & $\begin{array}{c}4 \\
(6.67)\end{array}$ & $\begin{array}{c}6 \\
(10)\end{array}$ & $\begin{array}{c}38 \\
(12.67)\end{array}$ \\
\hline & Readymade & $\begin{array}{c}23 \\
(41.07)\end{array}$ & $\begin{array}{c}32 \\
(53.33)\end{array}$ & $\begin{array}{c}35 \\
(58.33)\end{array}$ & $\begin{array}{c}40 \\
(66.67)\end{array}$ & $\begin{array}{c}39 \\
(65)\end{array}$ & $\begin{array}{c}169 \\
(56.33)\end{array}$ \\
\hline & Both & $\begin{array}{c}26 \\
(46.42)\end{array}$ & $\begin{array}{c}17 \\
(28.33)\end{array}$ & $\begin{array}{c}15 \\
(25)\end{array}$ & $\begin{array}{c}16 \\
(26.67)\end{array}$ & $\begin{array}{c}15 \\
(25)\end{array}$ & $\begin{array}{c}89 \\
(29.67)\end{array}$ \\
\hline
\end{tabular}

Figure in parenthesis indicate \%age

Table.3 Distribution of NR Buffalo farmers according to feeding of common salt, silage feeding and feeding of urea molasses block

\begin{tabular}{|c|c|c|c|c|c|c|c|}
\hline \multirow[t]{2}{*}{ Parameter } & \multirow[t]{2}{*}{ Category } & \multicolumn{2}{|c|}{ ACZ I } & \multirow{2}{*}{$\begin{array}{c}\text { ACZ II } \\
\substack{\text { Frz } \\
(n=60)}\end{array}$} & \multirow{2}{*}{$\begin{array}{c}\text { ACZ III } \\
\begin{array}{c}\text { Moga } \\
(n=60)\end{array}\end{array}$} & \multirow{2}{*}{$\underset{\substack{\text { Grd } \\
(\mathbf{n}=60)}}{\text { ACZ IV }}$} & \multirow{2}{*}{$\begin{array}{l}\text { Overall } \\
(\mathrm{n}=300)\end{array}$} \\
\hline & & $\begin{array}{c}\text { Asr } \\
(n=60)\end{array}$ & $\underset{(\mathbf{n}=60)}{\mathbf{T T}}$ & & & & \\
\hline \multirow{2}{*}{$\begin{array}{l}\text { Feeding of } \\
\text { common } \\
\text { salt }\end{array}$} & Yes & $\begin{array}{c}50 \\
(83.33)\end{array}$ & $\begin{array}{c}47 \\
(78.33)\end{array}$ & $\begin{array}{c}43 \\
(71.67)\end{array}$ & $\begin{array}{c}48 \\
(80)\end{array}$ & $\begin{array}{c}46 \\
(76.67)\end{array}$ & $\begin{array}{l}234 \\
(78)\end{array}$ \\
\hline & No & $\begin{array}{c}10 \\
(16.67)\end{array}$ & $\begin{array}{c}13 \\
(21.67)\end{array}$ & $\begin{array}{c}17 \\
(28.33)\end{array}$ & $\begin{array}{c}12 \\
(20)\end{array}$ & $\begin{array}{c}14 \\
(23.33)\end{array}$ & $\begin{array}{c}66 \\
(22)\end{array}$ \\
\hline \multirow[t]{2}{*}{$\begin{array}{l}\text { Silage } \\
\text { feeding }\end{array}$} & Yes & $\begin{array}{c}11 \\
(18.33)\end{array}$ & $\begin{array}{c}18 \\
(30)\end{array}$ & $\begin{array}{c}24 \\
(40)\end{array}$ & $\begin{array}{c}26 \\
(43.33)\end{array}$ & $\begin{array}{c}10 \\
(16.67)\end{array}$ & $\begin{array}{c}89 \\
(29.67)\end{array}$ \\
\hline & No & $\begin{array}{c}49 \\
(81.67)\end{array}$ & $\begin{array}{c}42 \\
(70)\end{array}$ & $\begin{array}{c}36 \\
(60)\end{array}$ & $\begin{array}{c}34 \\
(56.67)\end{array}$ & $\begin{array}{c}50 \\
(83.33)\end{array}$ & $\begin{array}{c}211 \\
(70.33)\end{array}$ \\
\hline \multirow{2}{*}{$\begin{array}{l}\text { Feeding of } \\
\text { Urea } \\
\text { Molasses } \\
\text { Block }\end{array}$} & Yes & $\begin{array}{c}4 \\
(6.67)\end{array}$ & $\begin{array}{c}15 \\
(25)\end{array}$ & $\begin{array}{c}7 \\
(11.67)\end{array}$ & $\begin{array}{c}9 \\
(15)\end{array}$ & $\begin{array}{c}2 \\
(3.33)\end{array}$ & $\begin{array}{c}37 \\
(12.33)\end{array}$ \\
\hline & No & $\begin{array}{c}56 \\
(93.33)\end{array}$ & $\begin{array}{c}45 \\
(75)\end{array}$ & $\begin{array}{c}53 \\
(88.33)\end{array}$ & $\begin{array}{c}51 \\
(85)\end{array}$ & $\begin{array}{c}58 \\
(96.67)\end{array}$ & $\begin{array}{c}263 \\
(87.67)\end{array}$ \\
\hline
\end{tabular}

Figure in parenthesis indicate \%age 
Table.4-Distribution of NR Buffalo farmers according to water availability, chopping of green fodder in different agroclimatic zones of Punjab

\begin{tabular}{|c|c|c|c|c|c|c|c|}
\hline \multirow[t]{2}{*}{ Parameter } & \multirow[t]{2}{*}{ Category } & \multicolumn{2}{|c|}{ ACZ I } & \multirow{2}{*}{$\begin{array}{c}\text { ACZ II } \\
\begin{array}{c}\text { Frz } \\
(n=60)\end{array}\end{array}$} & \multirow{2}{*}{$\begin{array}{l}\text { ACZ III } \\
\text { Moga } \\
(n=60)\end{array}$} & \multirow{2}{*}{$\begin{array}{c}\text { ACZ } \\
\text { IV } \\
\text { Grd } \\
(n=60)\end{array}$} & \multirow{2}{*}{$\begin{array}{l}\text { Overall } \\
(n=300)\end{array}$} \\
\hline & & $\begin{array}{c}\text { Ass } \\
(n=60)\end{array}$ & $\begin{array}{c}\text { TT } \\
(n=60)\end{array}$ & & & & \\
\hline \multirow{2}{*}{$\begin{array}{l}\text { Water } \\
\text { availability }\end{array}$} & 24 hrs & $\begin{array}{c}52 \\
(86.67)\end{array}$ & $\begin{array}{c}49 \\
(81.67)\end{array}$ & $\begin{array}{c}46 \\
(76.67)\end{array}$ & $\begin{array}{c}44 \\
(73.33)\end{array}$ & $\begin{array}{c}38 \\
(63.33)\end{array}$ & $\begin{array}{c}229 \\
(76.33)\end{array}$ \\
\hline & $\begin{array}{l}\text { When } \\
\text { needed }\end{array}$ & $\begin{array}{c}8 \\
(13.33)\end{array}$ & $\begin{array}{c}11 \\
(18.33)\end{array}$ & $\begin{array}{c}14 \\
(23.33)\end{array}$ & $\begin{array}{c}16 \\
(26.67)\end{array}$ & $\begin{array}{c}22 \\
(36.67)\end{array}$ & $\begin{array}{c}71 \\
(23.67)\end{array}$ \\
\hline \multirow{2}{*}{$\begin{array}{l}\text { Chopping of } \\
\text { Green } \\
\text { fodder }\end{array}$} & Yes & $\begin{array}{c}60 \\
(100)\end{array}$ & $\begin{array}{c}60 \\
(100)\end{array}$ & $\begin{array}{c}60 \\
(100)\end{array}$ & $\begin{array}{c}60 \\
(100)\end{array}$ & $\begin{array}{c}60 \\
(100)\end{array}$ & $\begin{array}{c}300 \\
(100)\end{array}$ \\
\hline & No & $\begin{array}{c}0 \\
(0)\end{array}$ & $\begin{array}{c}0 \\
(0)\end{array}$ & $\begin{array}{c}0 \\
(0)\end{array}$ & $\begin{array}{c}0 \\
(0)\end{array}$ & $\begin{array}{c}0 \\
(0)\end{array}$ & $\begin{array}{c}0 \\
(0)\end{array}$ \\
\hline
\end{tabular}

Figure in parenthesis indicate \%age

Figure.1 Distribution of Nili Ravi buffalo farmers according to method of feeding

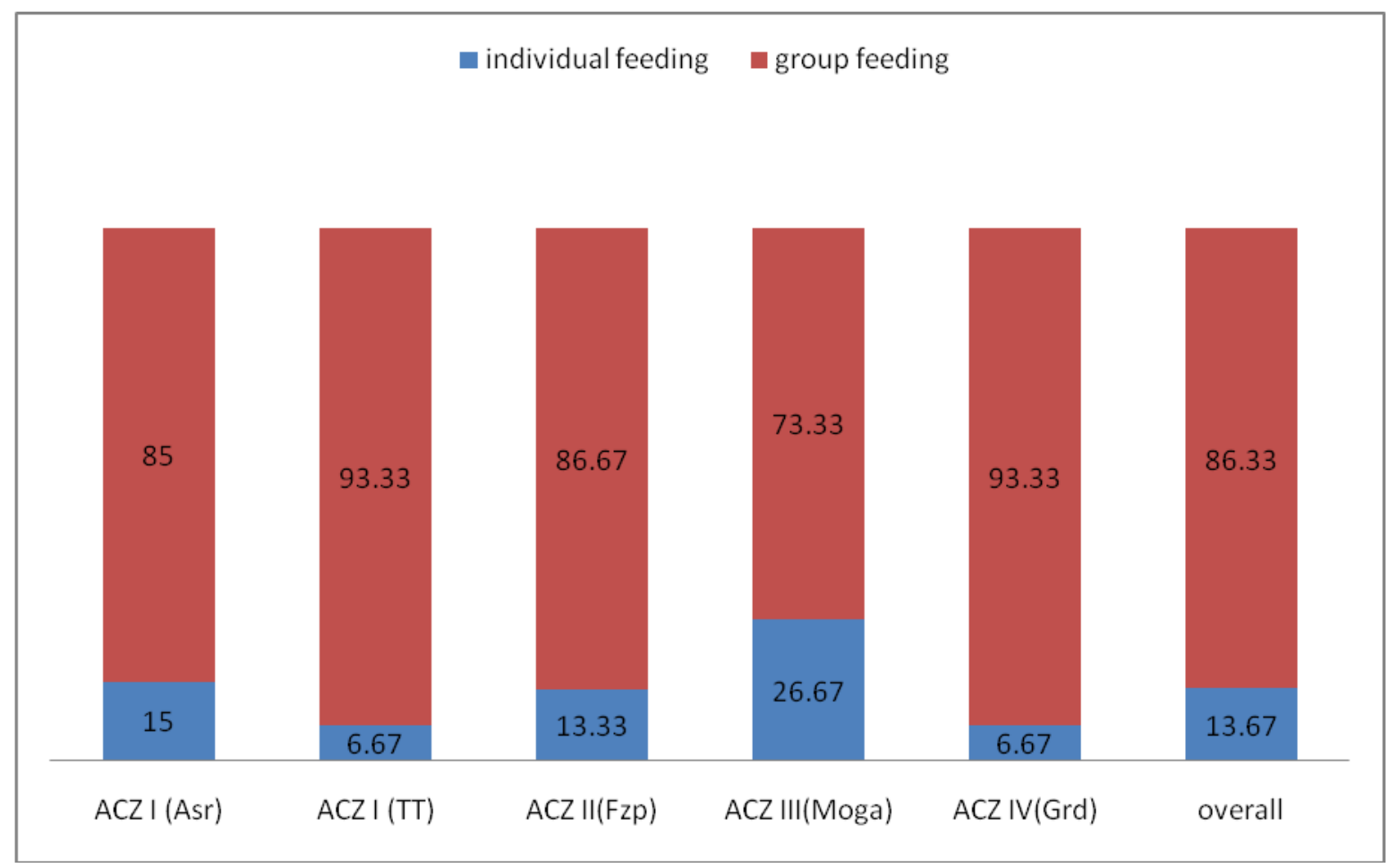


Figure.2 Distribution of Nili Ravi buffalo farmers according to silage feeding

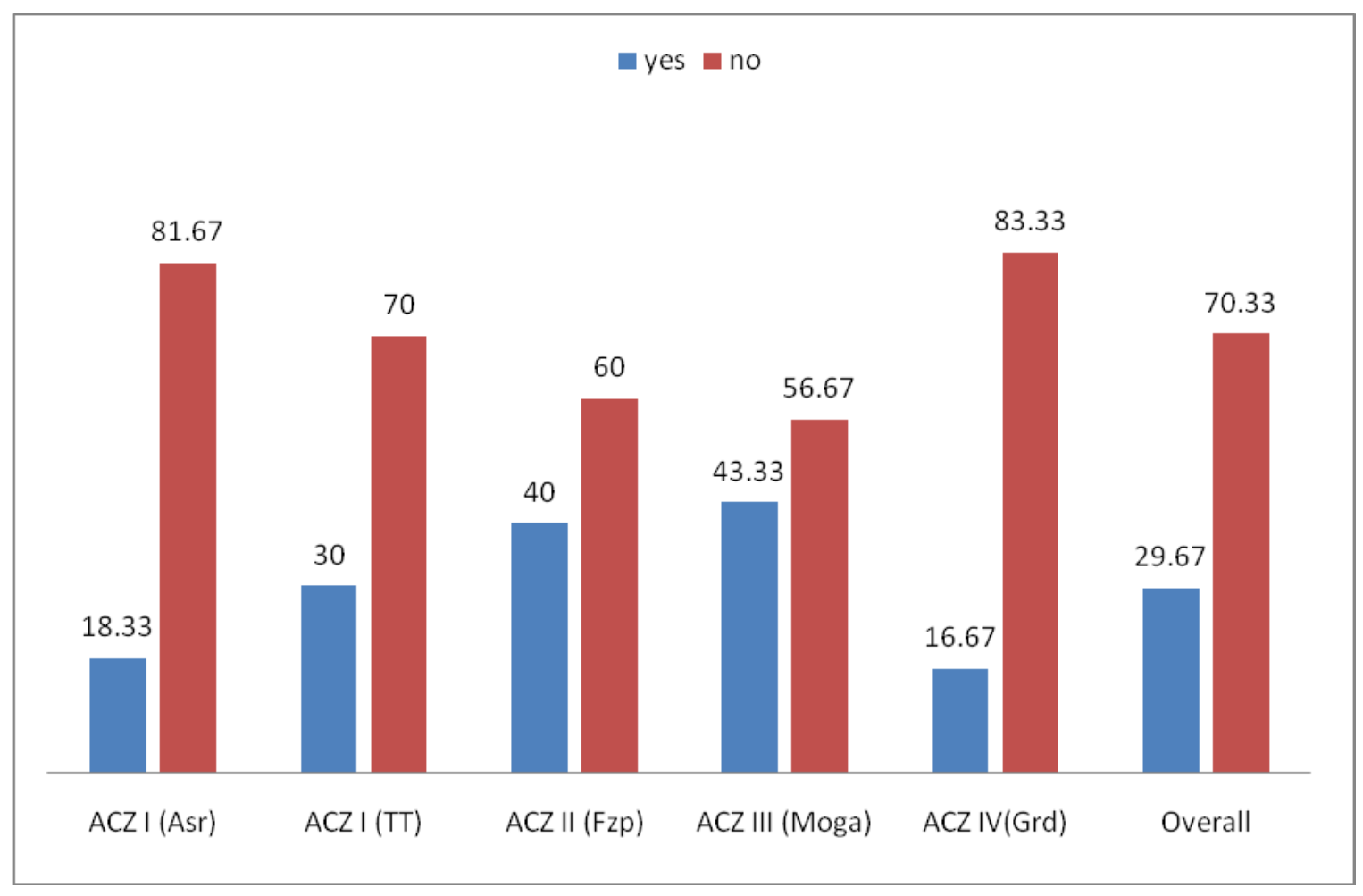

Figure.3 Distribution of Nili Ravi buffalo farmers according to feeding of Urea Molasses block

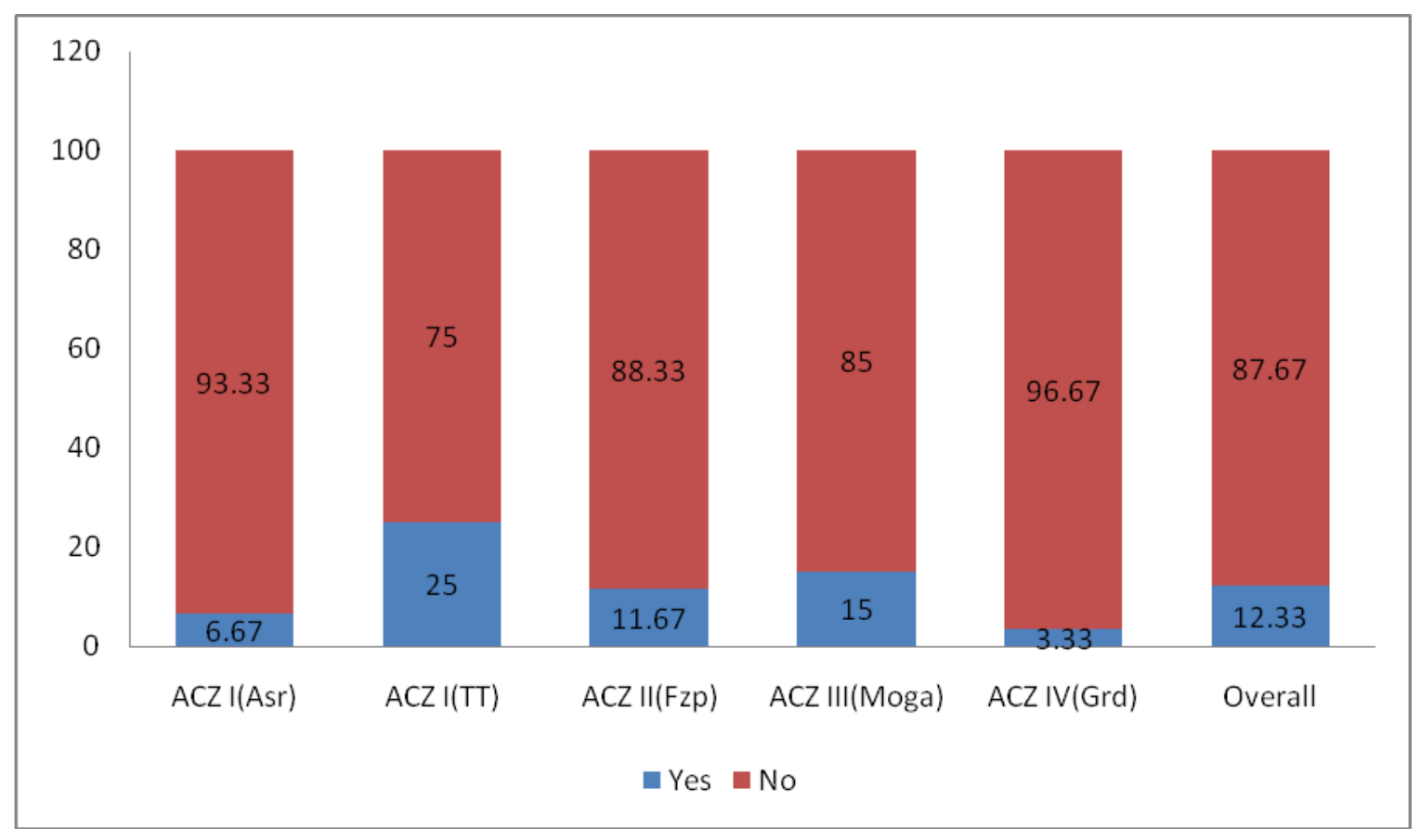




\section{Mineral mixture feeding}

Out of 300 Nili Ravi farmers, majority( 53.33 $\%)$ of farmers are feeding mineral mixture to the animals whereas rest of the $(46.67 \%)$ are not feeding the same as depicted in table 9 . Majority of the farmers $(73.33 \%)$ who are feeding mineral mixture were from ACZ III and minimum (18\%) were from ACZ I (Asr). For those who were not feeding, majority of the farmers $(70 \%)$ were from ACZ I (Asr) and minimum(26.67\%) were from ACZ III.

It can be summarised from the above that good number of dairy farmers were feeding mineral mixture to their animals. Still, more extension is required in the field to educate the farmers regarding the importance of the mineral mixture for optimum production in animals.

Similar results have been found by Laldinpuii (2013) in her study in Punjab.

Aulakh et al., (2011) had reported in their studies that $40.33 \%$ of the farmers were feeding mineral mixture to the animals.

\section{Concentrate feeding}

As represented in table no 2, maximum proportion $(98.67 \%)$ of the Nili Ravi farmers are feeding concentrate to the buffaloes and only $1.33 \%$ of the farmers are not feeding concentrate. Maximum proportion (100\%) of dairy farmers who were feeding concentrate were from ACZ I (TT), ACZ II, ACZ III \& ACZ IV and minimum proportion $(93.33 \%)$ were from ACZ I(Asr).

\section{Type of concentrate}

Table 2 depicts the distribution of 300 Nili Ravi buffalo farmers according to the type of concentrate they are feeding to the animals. Out of 300 , majority $(56.33 \%)$ of the farmers are feeding readymade concentrate followed by $29.67 \%$ are feeding both readymade and homemade type of concentrate and only $12.67 \%$ of farmers are feeding home made type of concentrate. For those who are feeding readymade concentrate, majority (66.67\%) were from ACZ III and minimum (41.07\%) were from ACZ I(Asr).

Maximum proportion (18.33\%) of the farmers who were feeding homemade type of concentrate were from ACZ I(TT) and minimum proportion $(6.67 \%)$ were from $\mathrm{ACZ}$ III.

Chavan et al., (2008) had reported in their studies that majority (54\%) of the farmers were feeding readymade type of concentrate to the animals.

\section{Feeding of common salt}

Table 3 represents the distribution of Nili Ravi buffalo farmers according to the feeding of common salt. Out of 300, majority of the farmers $(78 \%)$ are feeding common salt and $22 \%$ of the farmers are not feeding common salt. Maximum proportion $(83.33 \%)$ of the farmers those who were feeding common salt were from ACZ I(Asr) and minimum proportion(71.67\%) were from ACZ II. Those who were not feeding common salt, majority $(28.33 \%)$ were from ACZ III and minimum(16.67\%) were from ACZ I(Asr).

\section{Silage feeding}

Table 3 represents the distribution of Nili Ravi buffalo farmers according to the silage feeding. Only $29.67 \%$ of the farmers are feeding silage and rest $70.33 \%$ are not feeding. For those who are feeding, maximum farmers $(43.33 \%)$ were from ACZ III and minimum (16.67\%) were from ACZ IV.

For those who are not feeding, maximum proportion (83.33\%) was from ACZ IV and minimum proportion (60\%) was from ACZ II. 
Dev (2014) reported in their studies that $45.8 \%$ dairy farmers were feeding silage to their animals while $54.2 \%$ dairy farmers were not feeding silage to their animals. Similar results have been found by Laldinpuii (2013) in her study in Punjab.

Aulakh et al., (2011) had reported in their studies that only $8.06 \%$ of the buffalo farmers were feeding silage to the animals.

\section{Feeding of urea molasses block}

Table 3 represents the distribution of Nili Ravi buffalo farmers according to the feeding of urea molasses block to the animals. Only $12.33 \%$ of the farmers are feeding urea molasses block to the animals and major proportion $(87.67 \%)$ of the farmers are not feeding the same. Maximum proportion(25 $\%$ ) of the dairy farmers who were feeding were from ACZ I (Asr) and minimum proportion(3.33\%) were from ACZ IV.

\section{Water availability}

In table 4 it is represented that whether Nili Ravi farmers were providing water to the animals $24 \mathrm{hrs}$ or providing them water when needed. Out of 300 farmers, $76.33 \%$ of the farmers were providing water to the farmers $24 \mathrm{hrs}$ and $23.67 \%$ of farmers were providing water to the animals when needed at regular intervals of time. For those were providing water regularly, majority $(86.67 \%)$ of the farmers were from ACZ I (Asr) and minimum (63.33\%) were from ACZ IV.

\section{Chopping of green fodder}

Table 4 depicts that all the 300 Nili Ravi buffalo farmers chop green fodder before feeding them to the animals.

From above, it can be concluded that $63 \%$ of the farmers are giving extra diet to pregnant animals - maximum (73\%) -ACZ I (D1). 78\% of the farmers are adding salt to the diet of the animals -maximum (83.33\%)- ACZ I (D1). $29 \%$ of farmers are undergoing silage feeding-maximum (43\%) -ACZ III. 12.3\% farmers are feeding urea molasses block to animals - maximum (25\%) -ACZ I .Maximum feeding practices followed - ACZ I and minimum -ACZ IV.

\section{Acknowledgement}

The authors are thankful to the authorities of Guru AngadDev Veterinary and Animal Sciences University for providing the facilities to undertake this study.

\section{References}

20 ${ }^{\text {th }}$ Livestock Census. 2012. All India Report, Ministry of Agriculture, Department of Animal Husbandry, Dairying and Fisheries, Government of India, Krishi Bhawan, New Delhi, India.

Annual Report 2018-19, Department of Animal Husbandry, Dairying and Fisheries Ministry of Agriculture \& Farmer's Welfare, Government of India.

Buffalopedia, Department of Agriculture and Research, Indian Council of Agriculture Research, Ministry of Agriculture, Government of India.

Dairying In Punjab, A Statistical Profile, 2014, NDDB.

Ali, T., Rahman, A., Qureshi, M. S. Hussain, M.T. Khan, M. S. Uddin, S., Iqbal, M. and Han, B. 2014. Effect of management practices and animal age on incidence of mastitis in Nili Ravi buffaloes. Tropical Animal Health Production, 46: 1279-1285.

Aulakh, G.S., Yadav, J. S., and Singh, Rajbir. 2011. Knowledge level of dairy farmers regarding recommended buffalo management practices. Journal of 
Dairying Foods \& Home Sciences .30(2):147-149.

Chavan, A.A., Kalyankar, S. D., Khedkar, C. D., and Kalyankar, S. P. 2008. Studies on management practices of buffaloes in different agro climatic zones of Maharashtra. Indian Journal of Animal Research. 42(3):157-163.

Dar, P .A., Khan, A. A., Shah, A. A., Qadri, I. A., Manzoor, A. and Khan, H. M, 2017. Studies on Breeding and Feeding Practices of Buffalo in Vogue among Buffalo Farmers in Temperate Himalayan Region of Kashmir Valley. Indian Journal of Hill Farming (Special Issue): 83-87.

Dev K. (2014). 'Study on the feeding practices followed by dairy farmers in different agro-climatic zones of
Punjab'. M.V.Sc. Thesis, Guru AngadDev Veterinary and Animal Science University, Ludhiana.

Laldinpuii N. (2013). 'Studies on the dairy farming practices followed and training needs of dairy farmers in Punjab'. M.V.Sc. Thesis, Guru AngadDev Veterinary and Animal Science University, Ludhiana.

Siddiky, M.N.A. and Faruque, M.O. 2017. Buffaloes for dairying in South Asia: Potential, challenges and way forward. SAARC Journal of Agriculture 15(2): 227-239.

Vij, P. K. and Tantia, M. S. 2005. Status of Nili-Ravi buffaloes in India. National Bureau of Animal Genetic Resources 37: 75-81.

\section{How to cite this article:}

Navkiran Kaur, H.K. Verma, Jaswinder Singh and Kansal, S.K. 2020. Feeding Practices Followed by Nili Ravi Buffalo Farmers in Different Agroclimatic Zones of Punjab. Int.J.Curr.Microbiol.App.Sci. 9(10): 1136-1144. doi: https://doi.org/10.20546/ijcmas.2020.910.136 